Rev. $A N P(L L$, n. 6/7, p. 101-127, jan./dez. 1999

\title{
DE IMIGRANTES E MULATAS. MESTIÇAGEM E XENOFOBIA EM O CORTICCO DE ALUÍSIO AZEVEDO
}

Silvina Carrizo *

\begin{abstract}
RESUMO: () nosso trabalho se propõe responder a uma série de perguntas que emergem da leitura do romance () Cortiço de Aluísio Azevedlo quando lido na clivagem dos discursos sobre o nacional, a modernização e a questão da raça. Dessa maneira procuramos iluminar certos pontos básicos de interesse, tais como: por que aparece o personagem da mulata?" qual é sua relação com a tematização da mestiçagem?" como é visto este conceito? que ligação mantém com o conceito de modernização que emerge do texto? quais seriam os sentidos possíveis do protagonismo dos portugueses e da mulata? qual sua importância no contexto da literatura brasileira oitocentista?. Estas questões que surgem do romance de Aluisio Azevedo instigam a uma leitura que possa interligar certos assuntos que o texto manifesta ou cala em relação ao ideário nacional de final de século, ao lugar que ocupou Aluísio na época e sobre os graus de cooperação ou não da ficção na consolidação de um determinado discurso acerca da identidade nacional.
\end{abstract}

PALAVRAS-CHAVE: Aluísio Azevedo; romance; naturalismo brasileiro-nacionalismo; raça; mestiçagem; morlernização; imigração; cultura nacional.

or que em $O$ Cortiço aparece o personagem da mulata? Qual
é sua relação com a tematização da mestiçagem? Como é visto este conceito? Que ligação mantém com o conceito de modernização que emerge do texto? Quais seriam os sentidos possíveis do protagonismo dos portugueses e da mulata? Qual sua importância no contexto da literatura brasileira oitocentista?

* Universidade Federal Fluminense. 
CARRIZ(), Silvina. De imigrantes e mulatas. Mestiçagem e xenofobia...

Estas questões que surgem do romance de $\Lambda$ luísio $\Lambda$ zevedo instigam a uma leitura que possa interligar certos assuntos que o texto manifesta ou cala em relação ao ideário nacional de final de século, ao lugar que ocupou Nluísio na época e sobre os graus de cooperação ou não da ficção na consolidação de um determinado discurso acerca da identidade nacional.

\section{O QUE É ESSE POVO? QUEM SOMOS NÓS?}

Quem somos nós? Esta foi a pergunta mais recorrente dos escritores e intelectuais das últimas três décadas do século XIX brasileiro. Uma indagação que já não se enquadra no país romântico entendido como profundo, autêntico e puro, mas sim em um pretendido país real, com todas as suas virtudes e defeitos. Entre estes questionamentos e entre este "nós" vão aparecer "os outros": uma grande massa de trabalhadores, em sua maioria negros e mulatos, à qual se somam os imigrantes. Quem são esses outros, não necessariamente outros-políticos, mas outros-de classe, outros-de raça e cultura que fazem parte também deste "nós" que se quer civilizado?

Uma das grandes preocupações dos intelectuais ao incorporar o novo ideário científico foi a da mistura de raças, tarefa importantíssima através da qual se deviam comprovar as possibilidades e/ou impedimentos que traria a mestiçagem para o progresso burguês nos trópicos. Quem são os que passariam a integrar esse "nós" e como o fariam? Quem ficaria fora? Como situar-se frente ao processo modernizador - visto como indispensável e ao mesmo tempo inevitável - e à situação econômica, social e cultural do país?

O repertório científico da época havia criado analogias entre o corpo biológico e o corpo social, assim noçōes que provinham do primeiro campo rapidamente tornaram-se comuns ao campo do social. Um destes novos filtros interpretativos e talvez um dos que com mais êxito se difundiu foi o 
chamado darwinismo social que, consolidado por Spencer, baseava-se nas teorias de Darwin sobre a evolução das espécies e a seleção natural. O darwinismo social serviu, em grande medida, de conteúdo científico para justificar o liberalismo econômico e seu vínculo poderoso e perigoso com o racismo. Dentro deste universo ideológico se passa a questionar, no seio das teorias mais extremas, a viabilidade das raças mestiças e por extensão dos países mestiçados, como um desdobramento da propagação, nas últimas décadas do século passado, do segundo e grande colonialismo europeu.

O futuro e o progresso do Brasil, a abolição do trabalho escravo e a necessidade de promover a imigração - circunstâncias nas quais se jogava a imagem do país, tanto pela atração de imigrantes, quanto pelos investimentos de capitais estrangeiros - geraram no âmbito das elites todo um sistema de interpretação da nação que tentava adequar as teorias racistas à realidade racial do Brasil. $\mathrm{O}$ problema principal era a presença do negro, não mais escravo, reconhecido agora por sua cor. Um sistema complexo e particular foi-se criando, sistema que ia gradualmente distanciando a imagem da nação do negro e aproximando-a do "mestiço". No universo desta interpretação, o mestiço teria absorvido a população negra e indígena e, por outro lado, continuaria obviamente se misturando até "branquearse". O reconhecimento da mestiçagem como algo positivo havia necessitado, por sua vez, de toda uma estratégia teórica através da qual basicamente negavam-se à teoria racista européia (Gobineau, Agassiz, Laplanche) dois de seus pressupostos: o caráter inato das diferenças raciais e a consideração dos sangues mestiçados como degenerados.

O sistema complexo e particular a que aludimos foi conhecido como ideal de branqueamento; nele, a identidade mestiça não é compreendida como identidade plural, nem aberta, mas como o processo pelo qual uma raça superior pode assimilar as inferiores. Esta teoria do branqueamento se, por um lado, realça a identidade mestiça do povo brasileiro - criando uma diferença positiva em relação a outros países - é simultaneamente um 
(ARRIZ(), Silvina. De imigrantes e mulatas. Mestiçagem e xenofobia...

mecanismo de justificação do domínio sobre "os outros" brasileiros de cor. $\mathrm{O}$ ideal de branqueamento não pode ser compreendido sem considerar-se ao mesmo tempo a problemática da imigração, já que se articula no contraponto da construção e consolidação de uma identidade nova de nação - uma nação moderna, à altura das idéias e do avanço da nova investida capitalista - a partir de contundentes filtros interpretativos da sociedade configurados pelas noções que a teoria científica européia apresentava e que significavam, por sua vez, distintas formas de domínio.

É neste sentido que o romance $O$ Cortiço se nos afigura como um arquivo da memória da época. Nele emergem situações, relações e vocabulário que falam da nação em processo de modernização: trabalho livre, ascensão social, imigrantes, pobreza, trabalhadores, moradias precárias, transformações, conquistas. $\Lambda$ modernização se esboça como um processo autoritariamente individualista e de escalada social na qual somente os mais aptos ascenderiam - darwinismo social cuja melhor metáfora nos oferece o par João Romão/Bertoleza - e, simultaneamente, como um processo de organização - pensemos na remodelação do cortiço São Romão. $\Lambda$ tematização do mundo do trabalho e das relações em torno dele nos proporciona o enlace de duas problemáticas que o país precisou enfrentar: a abolição da mão-de-obra escrava e a entrada do imigrante ${ }^{1}$. Enquanto a festa aos domingos no cortiço confraterniza, o trabalho é visto como uma luta e o mundo do capital contribui para gerar e fomentar sectarismos ${ }^{2}$.

Nluísio constrói seu texto-arquivo permeado pelo imperativo da modernização e sem poder escapar da prerrogativa da identidade nacio-

1 Na época, a grande pressão externa contra o trabalho escravo e o crescimento econômico bem sucedido dos Estados Unidos, atribuído em grande parte à imigração, geravam concepções nas quais modernização implicava trabalho livre e imigração.

2 No romance são apresentados terríveis sectarismos e hierarquias por meio de um jogo de simetrias rígidas e em sua maioria impenetráveis, entre as quais se destacam as que fazem referência ao em cima/ embaixo e que, como já indicou Candido, só podem ser galgadas por João Romão visto ser ele o único acumulador de capital. Cf. Candido, A. "De cortiço a cortiço", in: $O$ discurso e a cidade. São Paulo: Duas Cidades, 1993: 123-152. 
Rev. $A N P() L L$, n. 6/7, p. 101-127, jan./dez. 1999

nal. Quem somos? Parece ser uma das tantas questões que o texto necessita expor. Deste modo torna-se notavelmente sugestivo a narrativa precisar da mulata ante a proximidade do imigrante, centrar-se em um tipo de português - o tipo conquistador, que quer ascender socialmente - e, finalmente, apresentar os trabalhadores pobres como pano de fundo entre os que chegam - os Miranda, os João Romão -, os que perdem - os Firmo, os Finório, as Bertolezas - e os que são espetáculo e agentes de acomodação as Ritas Baianas. O texto consegue, desta maneira, trabalhar com a presença de uma forte estruturação de classe e suas implicações com o problema da raça.

Ante a proximidade do imigrante, o discurso do nacional absorve um outro discurso, o da raça, e uma formulação já então bastante assimilada, a da mestiçagem ${ }^{3}$. O narrador enfatiza em relação a Jerônimo e Rita Baiana:

"Naquela mulata estava o grande mistério, a síntese das impressões que ele recebeu chegando aqui: ela era a luz ardente do meio-dia; ela era 0 calor vermelho das sestas da fazenda; era o aroma quente dos trevos e das baunilhas, que $o$ atordoara nas matas brasileiras; era a palmeira virginal e esquiva que se não torce a nenhuma planta; era o veneno e era o açúcar gostoso; era o sapoti mais doce que o mel e era a castanha do caju, que abre feridas com o seu azeite de fogo; ela era a cobra verde e traiçoeira, a lagarta viscosa, a muriçoca doida, que esvoaçava havia muito tempo em torno do corpo dele, assanhando-lhe os desejos, acordando-lhe as fibras embambecidas pela saudade da terra, picando-lhe as artérias, para lhe cuspir dentro do sangue uma centelha daquele amor setentrional, uma nota daquela música feita de gemidos de prazer, uma larva daquela nu-

3 Algumas questões fundamentais acerca da mestiçagem no Brasil e sua relação com a identidade nacional já tinham sido apresentadas e propostas por intelectuais estrangeiros como Denis e Von Martius (entre as décadas de 1830 e 1840). Ambos haviam sido figuras importantíssimas dentro das instituições do Segundo Império e tinham uma relação cordial com Dom Pedro. De qualquer modo, embora o universo discursivo tenha preparado imaginariamente o conceito de "mestiço", devemos considerar que o alto grau de diversidade étnica visível e a experiência traumática da escravidão são a base real da construção imaginária dessa identidade mestiça. 
CARRIZO, Silvina. De imigrantes e mulatas. Mestiçagem e xenofobia...

vem de cantáridas que zumbiam em torno da Rita Baiana e espalhavamse pelo ar numa fosforescência afrodisíaca". (Azevedo,1993: 64)

Como em um vaivém indefinido, o narrador concentra na mulata uma impressionante cadeia semântica que se ancora no olhar ambivalente que recai sobre o sujeito mestiço, a natureza e a mulher. Esta cadeia semântica se constrói em e pelo contraponto que significa refletir acerca da nação, evidenciando a instabilidade entre o local e o universal; pensemos, inclusive, que a seguinte frase agrega: "Isto era o que Jerônimo sentia, mas o que o tonto não podia conceber" (Azevedo, 1993: 64).

Se a mulata é a síntese das impressões, também o é em relação ao imigrante. Se ela é a luz, o aroma e a palmeira, isto se dá porque foi incorporada à natureza, a seu meio. Esta natureza paradisíaca e atraente, por sua vez, aparece assim na analogia com uma outra, a européia. E se, paradoxalmente, revela-se ao mesmo tempo como víbora, muriçoca, mosquito, ou seja, veneno e açúcar, é porque recebe a contraparte da carga semântica, a pejorativa. Rita é mulher, sexo, paixão e, do mesmo modo, é quem faz com que o homem se perca no prazer e na bebida. Rita é mulher, é natureza, é clima e é mulata. Perfila-se assim um encadeamento entre mulher, natureza e pátria que exerce sobre o personagem da mulata a pressão de identificá-la com o nacional, estando por isso mesmo esta concepção do nacional sujeita a uma contradição sem saída, visto que um personagem mestiço é desde o princípio, dentro da política do texto, um personagem volúvel, ocioso e que necessita ainda de umas pinceladas para seu aperfeiçoamento.

Ser espetáculo, ser ambivalente e não pertencer ao mundo do trabalho, "o defeito da vadiagem", são traços que constróem a imagem da mulata. O personagem da mulata, ao estar relacionado a um ideário do nacional, fica aprisionado em uma necessária e eficiente estereotipação, pois, ao entender que este personagem é a síntese, o mestiço torna-se o representante da identidade brasileira. 
Rev. ANPOLL, n. 6/7, p. 101-127, jan./dez. 1999

A questão do nacional no texto aparece como um tipo de "ethos" do povo, cuja base está mantida pelos filtros interpretativos da raça e do meio. A interligação de raça com cultura colabora na construção de um "caráter nacional" diferencial para o povo $0^{+}$.

Aluísio insiste em querer encontrar um estereótipo totalizador para o nacional, um personagem que dê conta do espírito do povo, mas... de todo esse nós? ou deles, desses outros?

A mestiça tornou-se elemento exótico que atrai o estrangeiro e o ajuda no seu abrasileiramento; contudo, enquanto atua como agente de acomodação do imigrante ${ }^{5}$, ela consegue branquear-se,

“(...) mas desde que Jerônimo propendeu para ela, fascinando-a com a sua tranqüila seriedade de animal bom e forte, o sangue da mestiça reclamou os seus direitos de apuração, c Rita preferiu no europeu o macho de raça superior. $\mathrm{O}$ cavouqueiro, pelo seu lado, cedendo às imposições mesológicas, enfarava a esposa, sua congênere, e queria a mulata, porque a mulata era o prazer, era a volúpia, cra o fruto dourado e acre destes sertões americanos, onde a alma de Jerônimo aprendeu lascívias de macaco e onde seu corpo porejou o cheiro sensual dos bodes". (Azevedo, 1993: 132)

O determinismo da raça e do meio é a política do texto da qual não há saída; se a mulata é o agente ambiental de aclimatação do europeu aos trópicos, o europeu é a raça superior, ou seja, branca e portanto civilizada

+ A analogia entre a biologia e o social foi o gérmen de teorias como as do darwinismo social e da estética naturalista, analogia da qual Aluísio não escapa e que em seu romance serve como forma de comprecnder $\mathrm{e}$ analisar. Por outro lado, $\mathrm{c}$ a modo de reforço, essa mesına analogia alimentou o racismo, tanto $\mathrm{em}$ sua teoria como em sua prática.

5 Agente de contato e/ou agente de acomodação são conceitos que provêm da antropologia e têm sido muitas vezes utilizados nas políticas de imigração estatais. Ambos os conceitos aludem à necessidade de um fator nacional, geralmente considerado próprio, para contribuir na assimilação das culturas c/ou acomodação, atuando, muitas vezes, como um tipo de identidade que conforma o "ser nacional". À respeito, ef. Seyferth, G. "A invenção da raça e o poder discricionário dos estereótipos", in: Anuário Antropológico / 93, Rio de Janeiro: Tempo Brasileiro, 1995: 175-203. Por outro lado, pensemos na mulata como um personagem literário, pictórico, publicitário e culturaimente recorrente. 
CARRIZO, Silvina. De imigrantes e mulatas. Mestiçagem e xenofobia...

com a qual o mestiço brasileiro conseguirá perder-se na trama das cores para transformar-se em branco.

O branquear-se - a questão de melhorar a raça - é exposto como um desejo, uma aspiração naquelas mulheres de classe baixa; isto é, não só aparece em Rita, mas está também em outra mestiça, Bertoleza: "Ele propôs-lhe morarem juntos, e ela concordou de braços abertos, feliz em meter-se de novo com um português, porque, como toda cafuza, Bertoleza não queria sujeitar-se a negros e procurava instintivamente o homem numa raça superior à sua". (Azevedo, 1993: 16). 0 branquear-se aqui só faz referência à questão da raça, ocultando a possível relação entre matrimôniocom-imigrante-branco = ascensão social.

É interessante observar como Aluísio constrói este paralelo entre ambas as mestiças, em uma narrativa sumamente simétrica como é $O$ Cortiço, o ponto de interseção entre elas é justamente o tema da raça e sua condição de mestiças - a problemática da ascensão social não as caracteriza. Rita desperdiça dinheiro e Bertoleza o economiza para alforriar-se e o confia a seu amante. Mas a elas serão outorgados papéis diferentes. Vejamos o caso de Bertoleza: embora seja sua condição de ex-esclava, na política do texto, o fator que não lhe permite representar a síntese do Brasil, serve como panfleto abolicionista e seu suicídio se torna a denúncia do resultado de uma exploração selvagem ${ }^{6}$,
"(...) à medida que ele galgava posição social, a desgraçada fazia-se mais e mais escrava e rasteira. João Romão subia e ela ficava cá embaixo, aban- donada como uma cavalgadura de que já não precisamos para continuar a viagem". (Azevedo, 1993: 117, grifo nosso)

As tensões vêm à luz: o abolicionismo defendido arrasta paralelamente as marcas de um preconceito racial e contribui para refletir sobre o

\footnotetext{
6 Veremos no tópico "A conjuntura e suas tensōes" como a exploração selvagem se manifesta no texto como uma responsabilidade de um imigrante português, ou seja, como um tipo de ascensão social; transfere-se a responsabilidade desviando-a de seu verdadeiro centro: um limite ideológico do autor/narrador? xenofobia?
} 
Rev. ANPOLL, n. 6/7, p. 101-127, jan./dez. 1999

imaginário da época, se pensamos na experiência da escravidão e como esta alcança todos os setores sociais?

O poder do mestiço está em abrasileirar o estrangeiro, em ser uma síntese do deleite que aprisiona o outro; ao mesmo tempo, o mundo do mestiço é o do ócio, da festa e ele precisa branquear-se, isto é, ordenar-se, regulamentar-se, enfim, civilizar-se.

Agente de contato que contribui para nacionalizar o imigrante, mas pode deixá-lo fora do mundo do trabalho. Agente de contato que, fazendo parte do exótico-nacional, não encontra contudo saída no texto. Sublinhemos que Rita, sendo a síntese do Brasil, desaparece da narrativa sem nenhuma explicação - sua presença é reduzida proporcionalmente à ascensão social de João Romão -, do mesmo modo que, enquanto quase todos os personagens se transformam, a mulata permanece sempre a mesma. Digamos que sendo uma característica bem comum da estética naturalista o fato de que os personagens sofram transformações físicas ou morais por herança do meio, Rita está completamente alheia a este processo - reparese que João Romão deve vencer essa dificuldade, pois tem que aprender a lidar com o novo meio. Talvez isto suceda no caso da mulata, primeiro, porque sua particularidade principal é ser mestiça (e em tal caso há uma herança da raça) e, segundo, porque ao ser mestiça é simultaneamente meio: natureza e pátria, e por isso mesmo Rita Baiana pode ser agente de acomodação do imigrante europeu.

7 A este respeito, Roberto Schwarz ilumina: "Esquematizando, pode-se dizer que a colonização produziu, com base no monopólio da terra, três classes de população: o latifundiário, o escravo e o 'homem livre', na verdade dependente. Entre os primeiros dois a relação é clara, é a multidão dos terceiros que nos interessa. Nem proprietários, nem proletários, seu acesso à vida social e a seus bens depende materialmente dofavor; indireto ou direto, de um grande (...) Note-se ainda que entre essas duas classes é que irá acontecer a vida ideológica, regida em conseqüência, por este mesmo mecanismo (...) O favor é a nossa mediação quase universal - e sendo mais simpático que o nexo escravista, a outra relação que a colônia nos legara, é compreensível que os escritores tenham baseado nele a sua interpretação do Brasil, involuntariamente disfarçando a violência, que sempre reinou na esfera da produção" Schwarz, R. Ao vencedor as batatas. 4. ed. São Paulo: Duas Cidades, 1992: 16. 
CARRIZO, Silvina. De imigrantes e mulatas. Mestiçagem e xenofobia...

Poderíamos inferir que esta maneira de tematizar a mestiçagem faz parte de um discurso do nacional no qual a diferença de identidade se constrói a partir de uma argumentação marcada pela tensão entre o local e o transnacional. Pensar em um Brasil mestiço na época supunha, em parte, responder a um racialismo científico que servia de fundamento para um menosprezo em relação a países tropicais e mestiçados. Decorre daí que o mestiço seja absorvido pelo exótico, convertendo-se em apologia, o que faz ressaltar a diferença do tratamento discursivo que vários narradores românticos tinham dado ao índio, mas também ao mestiço ${ }^{8}$. Entretanto, o mestiço no texto figura paradoxalmente, dentro do espaço das simetrias, no universo do não-trabalho, do desperdício, da falta de economias e previsão sobre o futuro. Ou fora do mundo do trabalho - Rita ${ }^{9}$ - ou fora da vida - Bertoleza. A narrativa delineia um mestiço vencido, de modo que o pretendido discurso da diferença nacional não se sustente e apareça de forma superficial, como um adorno.

A ambivalência na cadeia semântica da mulata parece estar assim operacionalizando somente um de seus sentidos, aquele que se refere a seu caráter pejorativo. Ou seja, este tipo de adorno poderia estar ligado à crença na inferioridade racial e social do mestiço e, por extensão, a do brasileiro comum, quer dizer: os outros, os setores trabalhadores e pobres. Talvez seja aqui, neste ponto, que possamos entrever que Aluísio construiu o este-

${ }^{8}$ De um modo geral, e com os riscos que se corre, nos narradores românticos o tratamento do mestiço era marginal, mas sempre presente. Pensemos por exemplo em Iracema (1865) de Alencar, onde o filho da índia, Moacir, o primeiro brasileiro, é também um mestiço, embora não tenha rosto, nem voz, nem palavra; ou reflitamos no caso do personagem Isabel no romance $O$ Guarani (1857), do mesmo autor, mestiça preconceituosa, um tanto ressentida e a única que morre por erro próprio.

9 Neste sentido é possível pensar na variedade de tipos que circulaın nas página de $O$ Cortiço: Firmo e seu grupo, Libório, a cabocla velha, etc. Todos eles pertencem ao mundo do não-trabalho e estão unidos ao mundo da desordem. No caso de Libório, é interessante que mesmo acumulando dinheiro em seu colchão, ou seja economizando, esse dinheiro não provém do trabalho. 
Rev. $A N P() L L$, n. 6/7, p. 101-127, jan./dez. 1999

reótipo da mestiça como síntese de um caráter nacional, colocado ali, nos outros, à certa distância do "nós" 10 .

Lisonjeado em vista da diferença e de ser agente de contato, perdedor devido à sua condição inferior e portanto sem chance de civilizar-se se não se mistura com o agente civilizador, branco, o mestiço aparece inscrito na tensão e no paradoxo do processo abolicionista brasileiro: que fazer com esse povo? Um exotismo de adorno serve ao menos para dar-lhe um "jeitinho", sem que o texto imagine outras saídas possíveis, pois se há um caminho para João Romão, não há para Rita. O texto-arquivo do qual falamos consegue desta maneira iluminar a trama de ajustes e desajustes do imaginário da época.

\section{IMIGRAR, CONQUISTAR}

$\Lambda$ partir da década de 1870 os conglomerados habitacionais começam a reproduzir-se por toda a cidade do Rio de Janeiro, muitos deles se estabeleceram no bairro de Botafogo. Como conseqüência das condições socioeconômicas pelas quais atravessava o país, a cidade começou a produzir novos tipos de relações e apresentar novos personagens, entre eles os imigrantes. No caso específico de $O$ Cortiço, aparecem representados os

10 O naturalista Carl von Martius (1794-1868) na oportunidade do concurso aberto para ensaio histórico que promove o Instituto Histórico e Geográfico apresenta seu trabalho "Como se deve escrever a História do Brasil", trabalho que foi premiado em 1845 e publicado. Embora a questão central do ensaio seja a história do Brasil, Martius não pode desligá-la da conformação racial do país, isto é, não pode deixar de pensá-la através de um critério etnográfico, ao qual, inovando, acrescentará um exame das condições socio-econômicas da nação em formação. Para os efeitos de nosso trabalho, o importante é que será um dos primeinos em destacar que o fenômeno da mestiçagem é característico das classes baixas, que passará às classes altas e tornará o país mestiço; fenômeno que é, inclusive, visto com entusiasmo. Cf. Martius, Carl von: "Como se deve escrever a História do Brasil”, in: $O$ estado do direito entre os autóctones do Brasil. Belo Horizonte: Itatiaia; São Paulo: Edusp, 1982. É bom recondar que Silvio Romero polemizará sobre esta questão com o naturalista em sua História da Literatura Brasileira (1888). 
(AARIZ(), Silvina. De imigrantes e mulatas. Mestiçagem e xenofobia...

portugueses, em sua maioria comerciantes e caixeiros de comércio, e os italianos, vendedores de todo tipo de produtos e em geral ambulantes.

Que tipo de imigrantes representam dentro da narrativa os portugueses: Miranda, João Romão e Jerônimo. Como imaginavam o Brasil? Que relação estabelecem com o país de adoção?

Para Jerônimo, o único dos três que chega com a família (sua mulher conterrânea, Piedade, e sua filha, Marianita), o Brasil é um lugar de oportunidades: trabalho e melhora do nível de vida. Este casal de imigrantes pobres e trabalhadores entra no país na qualidade de colonos de uma fazenda. Jerônimo representa no texto o imigrante ao qual se oferece trabalho no campo - onde começa a ser gerada a necessidade da mão-deobra livre ante a nova onda de exportações de café e a lenta abolição da escravatura - e que logo é vítima de uma estafa por ser obrigado a trabalhar lado a lado com o escravo e sob coação, sendo desrespeitados os seus direitos de cidadania:

\begin{abstract}
"Jerônimo viera da terra, com a mulher e uma filhinha ainda pequena, tentar a vida no Brasil, na qualidade de colono de um fazendeiro, em cuja fazenda mourejou durante dois anos, sem nunca levantar a cabeça, e de onde afinal se retirou de mãos vazias e com grande birra pela lavoura brasileira. Para continuar a servir na roça tinha que sujeitar-se a emparelhar com os negros escravos e viver com eles no mesmo meio degradante, encurralado como uma besta, sem aspirações, nem futuro, trabalhando eternamente para outro". (Azevedo, 1993: 47).
\end{abstract}

Dada a situação terrível do campo, Jerônimo se muda com sua família para a Corte e lá também ambos terão que trabalhar muito para poder sustentar-se. Se o Brasil aparecia à distância como uma terra de oportunidades, o texto ressaltará que na verdade era necessário lutar muitíssimo. Referindo-se a este casal, o narrador assinala "os dois lutaram a princípio no Brasil” ( $\Lambda$ zevedo, 1993: 48). Até certo momento o texto destacará este português como metáfora do imigrante trabalhador, honrado, 
Rev. ANPOLL, n. 6/7, p. 101-127, jan./dez. 1999

habilidoso, sério, preocupado com a educação de sua filha e querendo progredir:

"Mas não foram só o seu zelo e a sua habilidade o que o pôs assim para a frente; duas outras coisas contribuíram muito para isso: a força de touro que o tornava respeitado e temido por todo o pessoal dos trabalhadores, como ainda, e talvez principalmente, a grande seriedade do seu caráter e a pureza austera dos seus costumes". (Azevedo, 1993: 48).

Este imigrante trabalhador que chega ao país em busca de oportunidades tem, contudo, certa particularidade que, como veremos, nem Miranda nem João Romão possuem: Jerônimo sente saudades. O casal sente melancolia depois da pesada jornada de trabalho e é nesse momento que seus costumes são descritos: a comida, a música, a guitarra, $o$ fado, tudo fala desse mundo cultural que eles estão preservando. Assim sendo, esses costumes são marcados na narrativa como "estrangeiros". Jerônimo, sendo o modelo de trabalhador - inclusive porque sabe lutar por seu salário - é o que está mais relacionado ao "estrangeirismo" e sobre ele será tematizado todo o processo de abrasileiramento que, paradoxalmente, acabará por deixá-lo fora desse mundo: seus costumes portugueses desaparecem, abandona sua mulher e sua filha, afasta-se do trabalho, amanceba-se com uma mulata, assassina Firmo e torna-se alcoólatra.

Antes de continuar com este personagem, vamos nos deter em Miranda e João Romão. A modernização que o texto narra, alegorizada no cortiço, ocorrerá fundamentalmente em função das relações entre estes dois imigrantes portugueses. Ambos serão unidos pela inveja e ressentimento, pela proximidade de suas casas e pelas formas como lidam com a ascensão social. A narrativa terá como eixo as estratégias pelas quais Romão sai de "baixo" para chegar "em cima", onde se encontrará com a promessa de casamento da filha de Miranda, que já é barão. 
(ARRIZO, Silvina. De imigrantes e mulatas. Mestiçagem e xenofobia...

Se há uma característica que falta a Miranda, é a do gosto pelo trabalho, além de ter horror à pobreza, o que gerou nele um "saber" para poder escapar-lhes, custe o que custar:

"Prezava, acima de tudo, a sua posição social e tremia só com a idéia de ver-se novamente pobre, sem recursos e sem coragem para recomeçar a vida, depois de se haver habituado a umas tantas regalias e afeito à hombridade de português rico que já não tem pátria na Europa". (Azevedo, 1993: 18)

De qualquer modo, o pouco que sabemos é que em algum momento teve que passar por penúrias, mas conseguiu não só ascender como manter o status através do silêncio, das aparências e evitando escândalos:

"Tinha inveja do outro, daquele outro português que fizera fortuna, sem precisar roer nenhum chifre; daquele outro que, para ser mais rico três vezes do que ele, não teve de casar com a filha do patrão ou com a bastarda de algum fazendeiro freguês da casa!" (Azevedo, 1993: 25)

Para este português rico, cuja pátria é agora o Brasil, não existe uma distância real entre a maneira como pensava o país e seu presente:

“(...) logo depois do seu casamento, respondendo para Portugal a um excolega que o felicitava, dissera que o Brasil era uma cavalgadura carregada de dinheiro, cujas rédeas um homem fino empolgava facilmente". (Azevedo, 1993: 25)

Exceto quando seu rival, João Romão, se contrapõe; é aí que Miranda oscila, sentindo que talvez, apesar de vendedor e miserável, tenha sido possível a seu vizinho enriquecer sem pagar nenhum tipo de hipoteca:

"Pensara fazer-se senhor do Brasil e fizera-se escravo de uma brasileira mal-educada e sem escrúpulos de virtude! Imaginara-se talhado para grandes conquistas, e não passava de uma vítima ridícula e sofredora!... 
Sim! No fim de contas qual fora a sua África?...Enriquecera um pouco é verdade, mas como?, a que preço? Hipotecando-se a um diabo, que the trouxera oitenta contos de réis, mas incalculáveis milhões de desgostos e vergonhas! Arranjara a vida, mas teve de aturar eternamente uma mulher que ele odiava!" (Azevedo, 1993: 25)

Miranda, ladino e inteligente para acomodar-se socialmente e para obter dinheiro, está permeado, tanto como seu rival, João Romão, em sua construção de tipos sociais, pela metáfora da conquista. Ambos são vencedores e, se Miranda deve hipotecar sua vida doméstica, João Romão terá que desvencilhar-se das marcas de um passado de pobreza que o envergonhariam e o deixariam mal diante da burguesia da época. O caminho de João Romão condiz justamente com o que Miranda mais odiava em seu oponente, aquelas marcas de classe, aquele cheiro de pobreza: "(...) custava-lhe a sofrer a escandalosa fortuna do vendeiro 'aquele tipo! Um miserável, um sujo, que não pusera um paletó, e que vivia de cama e mesa com uma negra!'". (Azevedo, 1993: 25) ${ }^{11}$

Por que falamos da metáfora da conquista? Miranda queria ser o senhor do Brasil e de fato - apesar de seu lamento ressentido - faz parte, com o título de barão, de uma burguesia de títulos nobiliários. O Brasil é, na ótica de Miranda, como um cavalo cheio de dinheiro, necessitando-se apenas dominá-lo com habilidade e sabedoria; além disso, Miranda se imaginava enquanto imigrante aventureiro feito para grandes conquistas: "Imaginara-se talhado para grandes conquistas, e não passava de uma vítima ridícula e sofredora!...Sim! no fim de contas qual fora a sua África?..." (Azevedo, 1993: 25). Sendo assim, tendo em vista o desenho do personagem de Miranda e colocando palavras em sua boca, o Brasil é sinônimo de "fazer a América" porque, além de tudo, seria sem esforço e só fariam falta certas habilidades para fazer e saber calar.

\footnotetext{
11 Caberia aqui destacar como a representação da pobreza de João Romão está vinculada à proximidade de uma negra - já não é chamada de "cafuza". Se negro é igual a pobre e portanto não está, imaginariamente, longe de escravo, o branco é o contrário.
} 
CARRIZO, Silvina. De imigrantes e mulatas. Mestiçagem e xenofobia...

Se em $O$ Cortiço a questão da ascensão social está trabalhada a partir do mais puro darwinismo social, esta resolução individualista, segundo a qual vencerão os mais aptos, fortes e inteligentes, manifesta-se através de diferentes meios que aparecem criticados, como no caso de Miranda, o casamento e o dote (além do mais, sua mulher, Estela, é brasileira); ou no caso de João Romão, o roubo (Bertoleza e o velho Libório) e a acumulação de capital unida à exploração. Isto no que se refere a estes dois protagonistas, mas aparece também, por exemplo, na questão da prostituição. Não havendo nenhuma das possibilidades já mencionadas, a prostituição torna-se importantíssima para as mulheres pobres, não importando a cor de sua pele. Entretanto, na política do texto, a condenação recai desde o princípio na figura do imigrante português e, com maior ênfase, na de João Romão e suas estratégias de escalada na sociedade.

$\Lambda$ tematização da ascensão social acumula sentidos através da proliferação de termos e imagens que aludem ao vencer, ao lutar, ao fazer a guerra, ao dividir em grupos, e que configuram o campo semântico do darwinismo social, prisma a partir do qual o autor/narrador ${ }^{12}$ constrói sua visão do mundo do cortiço ${ }^{13}$.

Enquanto o abrasileiramento de Jerônimo nos é contado em poucas páginas, a transformação em capitalista de João Romão é o grande núcleo da narrativa. Se Miranda tinha que calar as constantes traições de sua mulher em nome das aparências, João Romão terá que aprender a ser um

12 Se particularmente estamos observando dentro da narrativa a visão do cortiço que se esboça, a partir do narrador, situando-se quase sempre "cá embaixo", as relações autor / narrador não podem ficar fora de nosso assunto, visto supormos que o narrador é uma forma de desdobramento do autor. Além disso, Aluísio, como exemplo de escritor naturalista, fazia suas próprias observaçōes documentais e de alguma maneira ele também tinha que - ao contrário de seu narrador - descer ao mundo dessas moradias, disfarçar-se para ocultar-se e poder passar despercebido.

13 Não existe em Alú́sio, nem em seu romance, o menor tom de paródia que haveria, por exemplo, em Quincas Borba (1891) de Machado de Assis; neste romance, o lema "ao vencedor as batatas" serve justamente como elemento corrosivo de um paradigma científico que conquistou lugar como ideologia. No caso de Aluísio de Azevedo é necessariamente o prisma escolhido para poder captar e compreender essa presença da multidão que a cidade está absorvendo. 
bom burguês, questão em que nunca havia pensado, visto que era, dentro da economia do texto, o imigrante-poupador, que mesmo tendo dinheiro continua trabalhando e vivendo na mesma situação de pobreza e miséria como tinha começado:

\begin{abstract}
"Desde que a febre de possuir se apoderou dele totalmente, todos os seus atos, todos, fosse o mais simples, visavam um interesse pecuniário. Só tinha uma preocupação: aumentar os bens (...) E seu tipo baixote, socado, de cabelos à escovinha, a barba sempre por fazer, ia e vinha da pedreira para a venda, da venda às hortas e ao capinzal, sempre em mangas de camisa, de tamancos, sem meias, olhando para todos os lados, com o seu eterno ar de cobiça, apoderando-se, com os olhos, de tudo aquilo de que ele não podia apoderar-se logo com as unhas". (Azevedo, 1993: 22-23)
\end{abstract}

Apoderar-se, conquistar, com os olhos e com as mãos, isto é o que caracteriza João Romão, visto ser um trabalhador que não tem problema em "sujar as mãos" para acumular dinheiro, questão que incomoda profundamente a Miranda.

No entanto, é a descrição in extremis, no limite com o caricatural e o grotesco, o traço que confere a este personagem a dose necessária de censura. João Romão só iniciará sua transformação ao saber que seu vizinho de cima recebeu o título de barão. Ante o exagero de sua avareza, que é a sua marca de saber fazer fortuna, o delírio de converter-se em capitalista e com título de nobreza começará a tirar-lhe o sono. Neste delírio aparecerá também a idéia de conquista:

\footnotetext{
“(...) Vendeiro? Qual! Era o famoso, o enorme capitalista! O proprietário sem igual! O incomparável banqueiro, em cujos capitais se equilibrava a terra, como imenso globo em cima de colunas feitas de moedas de ouro. $\mathrm{E}$ viu-se logo montado a cavaleiras sobre o mundo, pretendendo abarcá-lo com as suas pernas curtas; na cabeça uma coroa de rei e na mão um cetro". (Azevedo, 1993: 91)
} 
CARRIZO, Silvina. De imigrantes e mulatas. Mestiçagem e xenofobia...

Como vimos, tudo o que esteja relacionado com ascensão social nestes dois personagens é visto em termos de conquista e o Brasil surge como o primeiro degrau do que se deve apoderar nessa aventura de progresso econômico.

Se a metáfora da conquista perpassa estes dois imigrantes, que são além do mais os dois grandes vencedores do texto, ainda que criticados, a narrativa evita outorgar-lhes essa carta cultural de serem assimilados ao Brasil. Mas, mesmo quando o evita o que aparece é algo bem diferente: Miranda é um português rico já sem pátria, casado com uma brasileira e conhecedor das artimanhas da burguesia a que pertence, cujos ares de grandeza parecem vir de sua mulher ${ }^{1+}$; João Romão aparece no final do romance como um perfeito capitalista, ajustando-se ao mesmo sistema hipócrita da burguesia abolicionista ${ }^{15}$, a ponto de casar-se com uma brasileira; o texto sutilmente expõe a questão:

"Ah! Ele, posto nunca o dissera a ninguém, sustentava de si para si nos últimos anos o firme propósito de fazer-se um titular mais graduado que o Miranda. E, só depois de ter o título nas unhas, é que iria à Europa, de passeio, sustentando grandeza, metendo invejas, cercado de adulações, liberal, pródigo, brasileiro, atordoando o mundo velho com o seu ouro novo americano!" (Azevedo, 1993: 164)

Para ambos, afastar-se da pátria de origem está associado a ter triunfado economicamente no Brasil; triunfar os torna brasileiros. Então, esta outra modalidade de assimilação que a narrativa reprime está também tramada pelos eixos vencer-perder, dado que se entende a vida como uma luta em que ganham os mais fortes, os mais aptos. Se triunfaram

14 Tramando o casamento com a filha de Miranda, Botelho comenta com João Romão sobre seu futuro sogro: “- O Miranda é bom homem, coitado! Tem lá suas fumaças de grandeza, mas não o podemos criminar... são coisas pegadas da mulher (...)”. (Azevedo, 1993: 117)

15 Lembremos que minutos depois de que Bertoleza seja entregue aos policiais, uma comissão de abolicionistas chega à casa de João Romão para "trazer-lhe respeitosamente o diploma de sócio benemérito" (Azevedo, 1993: 179) 
economicamente, ao mesmo tempo souberam vencer aquilo que os desviaria desse caminho de triunfos, ou seja: o fascínio da natureza, o clima e as mulatas. Uma vez mais, a narrativa parece não poder conciliar o Brasil econômico com o Brasil natural.

Paradoxalmente, é o "hércules" do texto, Jerônimo, o imigrantetrabalhador, aquele que aparece como vencido e, na lógica do texto, quem é vencido é conquistado; mas quem conquistou este português e o que diz a narrativa acerca desta outra conquista?

Desde o princípio, Jerônimo é o mais forte, o "homenzarrão". O que significa esta fortaleza? Essa força que Jerônimo possui, inata porque vem de sua condição de "branco superior", faz parte da imagem que se construía e se propagava acerca do imigrante europeu: o mais apto para o trabalho livre e pesado - por exemplo, das zonas dos cafezais - e, ao mesmo tempo, uma espécie de redenção gradual para tornar mais claro o rosto do país. Assim, Jerônimo, como já vínhamos demonstrando, consolida-se até certo ponto no exemplo paradigmático do imigrante-trabalhador, não só sabe organizar o trabalho e dar lucro ao patrão, como também conhece o valor de mão-de-obra no mercado. Em determinada passagem, entrevistado por João Romão para trabalhar, discutindo sobre o salário, o futuro amante de Rita lhe diz: "(...) Aposto a mão direita em como o senhor não encontra por cinqüenta mil-réis quem dirija a broca, pese a pólvora e lasque fogo, sem lhe estragar a pedra e sem fazer desastres". (Azevedo, 1993: 40).

Sendo o "hércules" da narrativa, só vence o mulato Firmo. A fortaleza física de Jerônimo, que era uma alusão ao trabalho, acaba transferindo-se para um outro campo de sentido. À medida que ele se abrasileira, resta-lhe apenas a força para matar o mulato, porque a fortaleza moral que também o configurava desaparece tão rápido quanto se torna amante da mulata, e acaba cometendo um assassinato. A força física se transfere para o mundo do malandro, do fora da lei, mundo que era do mulato Firmo. Toda a composição deste personagem é fronteiriça com a lei do 
(CARRIZ(), Silvina. De imigrantes e mulatas. Mestiçagem e xenofobia...

menor esforço - a indolência, a preguiça - e com o mundo do crime e do delito $^{16}$.

Firmo e Jerônimo representam, a princípio, dentro do romance, universos intransponíveis; entretanto, o português poderá passar de um universo a outro em virtude da intervenção de Rita. Na economia do texto, cremos que, embora Jerônimo ocupe o lugar de Firmo no que concerne ao tipo, não o substitui, visto que se Firmo foi morto dentro de seus próprios códigos de hombridade, Jerônimo vai diluindo-se pouco a pouco na bebida e sua força vai-se perdendo: "E o curioso é que, quanto mais ia ele caindo nos usos e costumes brasileiros, tanto mais os seus sentidos se apuravam, posto que em detrimento das suas forças físicas" (Lzevedo, 1993: 76).

E sem forças físicas e morais, Jerônimo pode somente contemplar e estimular seus sentidos:

\begin{abstract}
"Uma transformação, lenta e profunda, operava-se nele, dia a dia, hora a hora, reviscerando-lhe o corpo e alando-lhe os sentidos, num trabalho misterioso e surdo de crisálida. A sua energia afrouxava lentamente: fazia-se contemplativo e amoroso. A vida americana e a natureza do Brasil patenteavam-lhe agora aspectos imprevistos e sedutores que o comoviam; esquecia-se dos seus primitivos sonhos de ambição, para idealizar felicidades novas, picantes e violentas; tornava-se liberal, imprevidente e franco, mais amigo de gastar que de guardar; adquiria desejos, tomava gosto aos prazeres, e volvia-se preguiçoso resignando-se, vencido, às imposições do sol e do calor (...)" (Azevedo, 1993: 75)
\end{abstract}

Novamente, a alegorização do nacional passa pela idéia de um Brasil dos sentidos, identificado com a natureza, o clima e a mestiçagem. Em alguns momentos a narrativa chega inclusive a impregnar-se de uma retórica nacionalista que nos remete aos românticos, pois este tipo de exaltação do exótico recai no personagem-símbolo do índio e alude, inclusive, aos

16 A descrição mais rica e sintetizadora de Firmo se encontra no início do capítulo VII; devido à sua extensão, não a transcrevemos aqui. (AZEVEDO, 1993: 55-56) 
tempos da conquista do Brasil. A citação anterior, que se referia ao processo de transformação de Jerônimo, continua desta maneira:

\begin{abstract}
"(...) e volvia-se preguiçoso resignando-se, vencido, às imposiçôes do sol e do calor, muralha de fogo com que o espírito eternamente revoltado do último tamoio entrincheirou a pátria contra os conquistadores aventureiros". (Azevedo, 1993: 75) ${ }^{17}$
\end{abstract}

Nesta pequena citação aparece uma boa parte do inventário romântico nacionalista: retórica de exaltação, indianismo e ambigüidade no binômio conquistador/conquistado; elementos que outorgavam um critério de diferenciação com respeito à ex-metrópole e que, ao mesmo tempo, contribuíam para ocultar a violência da conquista e colonização portuguesas. Assim, este argumento ambíguo acerca da identidade nacional que permeia o romance de Aluísio absorve o estilo romântico de exaltação sob o prisma do determinismo do meio, do clima e da raça.

Para imigrantes como Jerônimo, é impossível escapar ao deleite de ser brasileiro e por sua vez isso é um completo risco, porque os vencedores terminam sendo os outros. Paradoxalmente, como fomos mostrando, abrasileirar-se na narrativa é um processo e estado que acarreta as mesmas ambigüidades que o sujeito mestiço e, simultaneamente, é uma peculiaridade que está na classe trabalhadora, nessa multidão que está cada vez mais presente na cidade e cuja cor compromete a identidade nacional. $\mathrm{O}$ abrasileirado e o mestiço emergem na narrativa como exaltados e vencidos ao mesmo tempo.

Do mesmo modo que grande parte da narrativa romântica brasileira, no romance de Aluísio o ponto de vista para ficcionalizar a nação - ou melhor, este nós, estes uns e estes outros - está comprometido com certos ideários do nacional que ainda são incapazes de poder transpor o

17 Cf. também outros trechos que mais parecem extraídos do repertório romântico que pertencentes a uma ótica naturalista. Ibid, ibidem:. 62- 63 e 103. 
(ARRIZ(), Silvina. De imigrantes e mulatas. Mestiçagem e xenofobia...

maniqueísmo entre o local e o transnacional. Maniqueísmo que, por outra parte, transforma-se num "mal estar" constante para os teóricos da época. Embora seja certo que o compromisso dos intelectuais das últimas três décadas do século passado foi realizar um balanço dos significados que a monarquia deixara e, para nosso caso mais específico, a literatura romântica, esse balanço e as novas formas de interpretação continuaram imbricadas a um imaginário ambíguo e a uma tensão entre a exaltação e o pessimismo.

\section{CONCLUSÃO: A CONJUNTURA E SUAS TENSŌES}

Como fomos destacando, $O$ Cortiço está sujeito a certo ideário nacional baseado na construção de uma cadeia semântica natureza-mulatapátria que une cada uma das três noções comprometidas, podendo alterar-se cada uma das posições que ocupam, com a incidência do determinismo do meio, do clima e da raça, o que acaba produzindo uma colisão de sentidos. Assim uma propensão à apologia e ao paradoxo, ao otimismo e à retração impregnam cada uma das noções, tornando-as ambíguas e em tensão, como assim também a cadeia em sua produção de sentidos.

Se as particularidades naturais do Brasil, um dia, renderam o conquistador, seduzindo-o, parece dizer-nos o texto, o português, ao estilo de João Romão e Miranda, continua conquistando e já não se rende ante a sensualidade envolvente do trópico; muito embora, o único imigrante conquistado pelo mundo dos sentidos seja o equivalente a um vencido no mundo da razão, da ordem, do trabalho.

$\mathrm{O}$ tema de quem somos e o questionamento acerca da viabilidade da civilização nos trópicos se entrecruzam de uma maneira tensa e tingem a narrativa de ares xenófobos, desviando as causas de seu centro. Quer dizer, quando estamos interpretando a alegoria da nação em processo de 
Rev. $A N P() L L$, n. 6/7, p. 101-127, jan./dez. 1999

modernização em $O$ Cortiço, constatamos uma forte crítica à crueldade de tal processo, o que por outra parte não implica uma falta de apoio. $\mathrm{O}$ cortiço, visto através dos olhos da estética naturalista de $\Lambda$ zevedo, emerge como a contraface do espetáculo da modernização, é o espetáculo impudico da pobreza que cresce dia a dia na cidade. Quadro decadente e ameaçante que não satisfazia em nada à elite e encontrava em Nluísio apoio para todo tipo de medida que "higienizasse" o Rio de Janeiro ${ }^{18}$.

Falávamos da crítica à crueldade da modernização, mas como aparece na narrativa? $\Lambda$ crítica, neste sentido, recairia nos modos de ascensão social de certo tipo de imigrante português. João Romão e Miranda são ambos ladinos e inteligentes, delineados como caçadores de fortunas brasileiras a qualquer preço e que obtêm sucesso e poder rapidamente. Como na narrativa o que se evita é a possibilidade de que eles também se tenham assimilado, ou seja, que se tenham abrasileirado, a crítica passará pelas formas de ascensão social ${ }^{19}$.

Silencia-se a possibilidade de que eles se tenham aclimatado ao país porque, dentro da política do texto, aclimatar-se significa render-se aos encantos dos sentidos. Ressaltar o lugar dos imigrantes portugueses - principalmente o de João Romão - por sua habilidade de enriquecer gera o tom xenófobo e, portanto, as causas que estariam produzindo tão descarnado processo se insinuam de uma forma velada e intencionalmente ideológica. $\mathrm{O}$ imigrante aparece como o bode-expiatório de um momento histórico que alcança níveis internacionais.

18 A respeito, Menezes reproduz um trecho da conversa mantida entre Aluísio e um amigo, na qual percebe-se a posição do autor e também se pode observar os modos pelos quais a elite imaginava esse momento de reurbanização da cidade: "Será com efeito possível que o Rio de Janeiro perca o seu velho feitio colonial português e dê em capital sadia e limpa (...) E a graça é que não veio tais notícias sem pensar logo no Bilac, porque ai, quando andávamos juntos por essas ruas cor de tujuco e cheiro de vasilhame sujo, levávamos a reconstruir platonicamente toda a cidade, arrasando os quarteirões, furando bairros, abrindo praças e até dando reviravoltas nas casas, como se elas fossem brinquedos." In: Menezes, Raimundo de: Aluísio Azevedo. Uma vida de romance. 1 ed. São Paulo: Livraria Martins, 1958: 296.

$\mathrm{O}$ tópico do português comerciante que triunfa no Brasil já aparecia em O Mulato (1881). 
(ARRIZ(), Silvina. De imigrantes e mulatas. Mestiçagem e xenofobia...

O romance de Aluísio, estando sujeito a um sentimento nacional que se expressa na tensão entre a apologia e o paradoxo, encontra-se também preso a um nacionalismo xenófobo ${ }^{20}$. Portanto, poderíamos acrescentar aqui que a representação do imigrante português está também carregada de ambigüidades ideológicas tanto como estão, ainda que com outros sentidos, o mestiço e a natureza tropical. Se o imigrante português, enquanto homem branco, é a "raça superior" que contribuirá para melhorar a raça mestiça brasileira e para trazer o progresso, produz-se um contra-sentido visto que, em vez de mestiçar-se, o imigrante apenas enriquece e explora justamente esse mesmo povo mestiço ${ }^{21}$. Por outro lado, se triunfa é porque não se deixou vencer pela natureza, pelas mulatas brasileiras, isto é: os que vencem não se abrasileiram. Para o caso, é ilustrativo que um dos últimos delírios de grandeza de João Romão seja o de ser presidente da comunidade portuguesa no Brasil e receber o título de Visconde. Em contrapartida, os que se assimilam, se abrasileiram e, ao ficarem fora da esfera do progresso, começam a engrossar a longa fila anônima dos vencidos.

\begin{abstract}
This paper is determined to answer a series of questions that rise upon reading the novel () Cortiço by Aluísio Azevedlo when read in the intersection of discourses about nationalism, modernization and race matter. This way, we
\end{abstract}

20 Desde 1822, com a Independência, houve um sentimento de lusofobia importante no seio da elite. Um sentimento, contudo, muito mais forte incrementou-se nas primeiras décadas da República, já que os portugueses detinham o controle do comércio em quase todas as cidades do país. Uma onda de propaganda antiportuguesa proliferou durante a presidência do marechal Floriano Peixoto (1891-1894), foram fundados jornais como $O$ jacobino e $O$ Nacional nos quais se discutiam problemas como os da lei de naturalização do estrangeiro, o protecionismo comercial, industrial e de propriedade. Cf. SKIDMORE, Th. Preto no Branco. Raça e nacionalidade no pensamento brasileiro. 2 ed. Rio de Janeiro: Paz e Terra, 1989. Preferentemente o Capítulo 3: "Política, Literatura e o sentimento brasileiro de nacionalidade antes de 1910": 95-141.

21 Nesta oportunidade, uma vez mais, o exemplo extremo da história de Bertoleza e João Romão é ilustrativo porque este português, na lógica do texto, jamais permaneceria com uma mulher de cor se isto acarretasse algum tipo de obstáculo em sua escalada social. Ascender é branquear-se e significa desvencilhar-se da "mancha escura". 
Rev. $A N P() L L$, n. 6/7, p. 101-127, jan./dez. 1999

tried to highlight a few basic points of interest such as: why does the character of the mulatto appear?, what is its relation with the tematization of the miscegenation?, how is this notion seen?, what link does it keep with the concept of modernization that rises from the text?', what would be the possible meaning of the protagonism of the portuguese and the mulatto?, what is its importance in the context of the brazilian literature of the eighteenth century?. These questions that appear from the novel by Azevedo lead to a reading that might link certain subjects that the text arouses or silents about the national imaginary of the end of the century, about the place that Azevedo occupied in his time and the level of cooperation, if there was any, of the fiction in the consolidation of a determined discourse about the national identity.

KEYWORDS: Aluísio Azevedo; novel; brazilian naturalism-nationalism; race; miscegenation; modernization; immigration-national culture.

\section{BIBLIOGRAFIA}

ANDERSON, B. (1993) Comunidades imaginadas. Reflexiones sobre el origen y la difusión del nacionalismo. México: Fondo de Cultura Económica.

AZEVEDO, A. (1993) O Cortiço (1890) São Paulo: Núcleo.

BENCHIMOL, J. L. (1992) Pereira Passos: um Haussmann tropical; a renovação urbana da cidade do Rio de Janeiro no início do século XX. Rio de Janeiro: Sec. Municipal de Cultura, Depto. Geral de Documentação e Informação Cultural, Divisão de Editoração.

BHABHA, H. (1990) Nation and Narration. Londres: Routledge.

BROCA, J. B. (1975) A vida literária no Brasil-1900. 3. ed. Rio de Janeiro: J. Olympio, Depto. de Cultura da Guanabara.

. (1991) Naturalistas, parnasianos e decadistas. Vida literária do realismo ao pré-modernismo. Campinas, São Paulo: Editora da UNICAMP.

CANDIDO, A. (1993) O discurso e a cidade. São Paulo: Duas Cidades.

. (1974) 1 passagem do dois ao três (contribuição para o estudo das mediações na análise literária). In: Revista de História. São Paulo, 100, L. tomo II: 787-799.

CANDIDO, S. (1997) Fronteiras da imaginação. Os românticos brasileiros: mestiçageme nação. Tese de mestrado. Universidade Federal Fluminense. Centro de Estudos Gerais. Instituto de Letras, (no prelo). 
(ARRIZ(), Silvina. De imigrantes e mulatas. Mestiçagem e xenofobia...

CARVALHO, J. M. de (1991) Os bestializados: o Rio de Janeiro e a República que não foi. São Paulo: Companhia das Letras.

COSTA, E. V. da (1994): Da Monarquia à República. Momentos Decisivos. 6. ed. São Paulo: Brasiliense.

DANTAS, P.(s/d) Aluísio Azevedo. Um romancista do povo. São Paulo: Melhoramentos (Col. Grandes Vultos das Letras, n. 12).

GOMES, R. C. (1994) Todas as cidades, a cidade: literatura e experiência urbana. Rio de Janeiro: Rocco.

HOSBAWN, E. (1991) Nações e nacionalismo desde 1870. São Paulo: Paz e Terra.

IANNI, O.(1988) Escravidão e Racismo. (2. ed. revista e aumentada) São Paulo: HUCITEC.

MARQUES, M. Jr. (1991) O realismo Grotesco em O Cortiço, in: Revista de Cultura Vozes "Meninas do Rio, Meninas da Rua", Ano 85, vol. LXXXV, set./out., n. 5.

. (1996) De estalagem a avenida: moderno mundo urbano em O Cortiço, artigo apresentado no V Congresso ABRALIC-Rio de Janeiro, julho-agosto.

MARTIUS, C. F. P. von (1982) Como se deve escrever a história do Brasil, in: O estado do direito entre os autóctones do Brasil. Belo Horizonte: Itatiaia; São Paulo: Edusp: 85-107.

MATOS, C. N. de (1994): A poesia popular na república das letras: Sílvio Romero Folclorista. Rio de Janeiro: FUNARTE/UFRJ.

MENEZES, R. de (1958) Aluísio Azevedo.Uma vida de romance. 1. ed. São Paulo: Livraria Martins.

ROMERO, S. (1949) História da Literatura Brasileira. 4. ed. (Organizada e com prefácio de Nelson Romero) Rio de Janeiro: José Olympio, 5 tomos.

SAID, E. (1990) Orientalismo. O Oriente como invenção do Ocidente. São Paulo: Companhia das Letras.

. (1994) Culture and Imperialism. New York: Vintage Books.

SCHWARCZ, L. M. (1987) Retrato em branco e negro: jornais, escravos e cidadãos em São Paulo no final do século XIX. São Paulo: Companhia das Letras.

. e R. da S. QUEIROZ (orgs.) (1996) Raça e Diversidade. São Paulo: Edusp: Estação Ciência: Edusp.

SCHWARZ, R. (1992) Ao vencedor as batatas. 4. ed. São Paulo: Duas Cidades.

SEVCENKO, N. (1995) Literatura como missão. Tensões sociais e criação cultural na Primeira República. 4. ed. São Paulo: Brasiliense.

SEYFERTH, G. (1995) A invenção da raça e o poder discricionário dos estereótipos, in: Anuário Antropológico/93. Rio de Janeiro: Tempo Brasileiro: 175-203. 
Rev. $A N P() L L$, n. 6/7, p. 101-127, jan./dez. 1999

SIKDMORE, Th. E. (1989) Preto no Branco. Raça e nacionalidade no pensamento brasileiro. 2. ed. Rio de Janeiro: Paz e Terra.

SUSSEKIND, F. (1984) Tal Brasil, qual romance?. Uma ideologia estética e sua história: o naturalismo. Rio de Janeiro: Achiamé.

VENTURA, R. (1991) Estilo tropical. História cultural e polêmicas literárias no Brasil, 1870-1914. São Paulo: Companhia das Letras. 